\title{
BIBLIOGRAFIA
}

Benjamin, Walter. Źródło dramatu żałobnego w Niemczech. Przeł. Andrzej Kopacki. Posł. Adam Lipszyc. Warszawa: Wydawnictwo Sic!, 2013.

Borowiec, Anna. „Album Orbis” Cypriana Norwida jako księga sztukmistrza. Gdańsk: Słowo/obraz terytoria, 2016.

Chlebowski, Piotr. Romantyczna silva rerum. O Norwidowym "Albumie Orbis". Lublin: Towarzystwo Naukowe KUL, 2009.

Feliksiak, Elżbieta. Poezja i myśl. Studia o Norwidzie. Lublin: Towarzystwo Naukowe KUL, 2001.

Gomulicki, Juliusz Wiktor. „Dodatek krytyczny. Metryki i objaśnienia”. Norwid, Cyprian. Pisma wszystkie. Tom 7. Warszawa: Państwowy Instytut Wydawniczy, 1973.

Iwaszkiewicz, Jarosław. „Fama”. Twórczość 6 (1956). S. 8-17.

Karpowicz, Agnieszka. Kolaż. Awangardowy gest kreacji. Themerson, Buczkowski, Białoszewski. Warszawa: Wydawnictwa Uniwersytetu Warszawskiego, 2007.

Kubler, George. Kształt czasu. Uwagi o historii rzeczy. Przeł. Jacek Hołówka. Warszawa: Państwowy Instytut Wydawniczy, 1970.

Norwid, Cyprian. Pisma wszystkie. Tom 2. Oprac. J.W. Gomulicki. Warszawa: Państwowy Instytut Wydawniczy, 1971.

Praz, Mario. Mnemosyne. Rzecz o powinowactwie literatury i sztuk plastycznych. Przeł. Wojciech Jekiel. Gdańsk: Słowo/obraz terytoria, 2006.

Rutkowski, Krzysztof. „Warburg i wąż”. Konteksty: Polska Sztuka Ludowa 2-3 (2011). S. 15-26.

Warburg, Aby. Narodziny Wenus i inne szkice renesansowe. Przeł. Ryszard Kasperowicz. Oprac. Katia Mazzucco. Gdańsk: Słowo/obraz terytoria, 2010.

\section{POSTAWY SPOEECZNE WOBEC INNEGO. PROCESY ADAPTACYJNE}

\author{
Eliza GrzelaK ${ }^{1}$ \\ (Uniwersytet im. Adama Mickiewicza w Poznaniu)
}

Edukacja - migracja. Edukacja międzykulturowa w kontekście kryzysu migracyjnego z perspektywy krajów V4. Red. E. Kledzik, M. Praczyk. Poznań: Media Rodzina, 2016. 239 S.

W 1999 roku państwa członkowskie Unii Europejskiej zobowiązały się do stworzenia spójnego systemu azylowego. Mając to na uwadze, Unia przyjęła Konwencję Dublińską (1990) i jej nowelizacje (2003, 2014), które wskazują odpowiedzialnego za prowadzenie postępowania azylowego. Ratyfikowano także dyrektywę, określającą

1 E-mail: kontakt@elizagrzelak.pl 
standardy recepcji uchodźców. Ponadto powołano Eurodac², wspólną bazę danych, która uniemożliwia składanie wniosków o status uchodźcy w kilku państwach.

Jednak kryzys migracyjny, który rozpoczął się w 2015 roku, obnażył słabość Unii Europejskiej w tym zakresie. Wszystkie decyzje, dotyczące imigrantów i uchodźców, przyjmowane są przez przywódców poszczególnych państw wspólnoty. Nawet implementacja prawa międzynarodowego jest często kwestionowana przez państwa przeciwne polityce "otwartych drzwi".

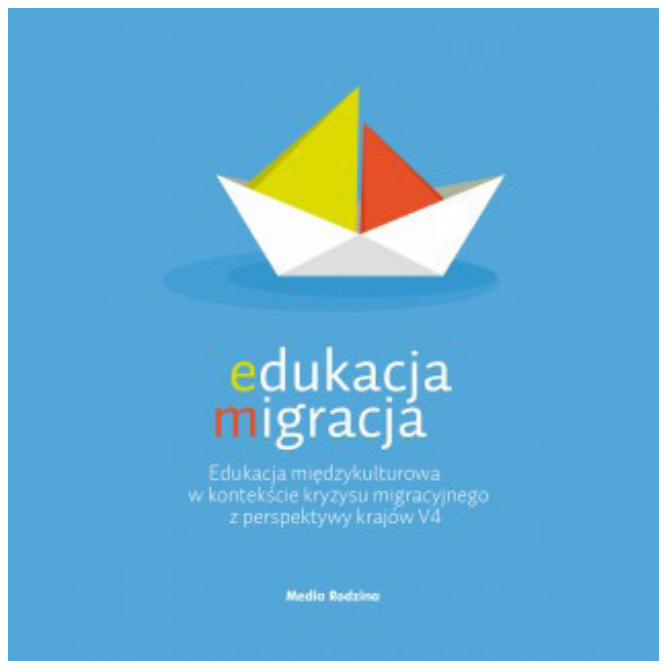

Problem nie ma podłoża ekonomicznego, jest to głównie efekt niskiego poziomu socjalizacji obywateli niektórych państw członkowskich, którzy boją się przede wszystkim zderzenia kultur. Nie zostali oni przygotowani do zmieniającego się świata, pozbawionego granic państwowych. Kłopoty, z którymi mierzy się dziś Europa, są obywatelom tych państw obce, nieznane zaś zawsze budzi strach i sprzeciw, pomimo tak poważnych trudności w relacjach interpersonalnych komunikacja międzykulturowa nadal nie jest przedmiotem edukacji społecznej.

Nie można już zatrzymać wędrówki ludów, będzie tylko zmieniała się jej przyczyna, wolność przemieszczania się - podążania za pracą, wodą, nowymi wrażeniami, przede wszystkim za pokojem - stała się immanentną cechą współczesnych społeczeństw (Hatalska). Dlatego szczególnie aktualne są pytania: jak zneutralizować wrogość wobec Innego, jak nawiązać z nim pozytywne relacje, jak definiować zagrożenia, będące wynikiem konfliktu kultur, i jak im przeciwdziałać.

Próbą odpowiedzi na nie jest publikacja pod redakcją Emilii Kledzik i Małgorzaty Praczyk, Edukacja - migracja. Edukacja międzykulturowa w kontekście kryzysu migracyjnego z perspektywy krajów V4, której niewątpliwymi zaletami są aktualność i szeroki kontekst prezentacji.

Dokonany przez redaktorki wybór artykułów, ilustrujący zróżnicowaną perspektywę badawczą, umożliwia poznanie problemów migracji - stosunku do Inności, edukacji na temat Innego, edukacji w środowisku interkulturowym, komunikacji międzykulturowej, ochrony prawnej Innego - z różnych punktów widzenia. Dla autorów zebranych tekstów istotna okazała się zarówno problematyka metodologiczna,

2 Rozporządzenie Rady Unii Europejskiej nr 2725/2000 z dnia 11 grudnia 2000 r. dotyczące ustanowienia systemu Eurodac do porównywania odcisków palców w celu skutecznego stosowania Konwencji Dublińskiej. 
jak i rzeczowa, zagadnienia pragmatyczne: rozpoznanie mowy nienawiści, techniki nauczania języka większości, poszukiwanie ekwiwalencji lingwistycznej w pracy tłumacza analizowane były w kontekście dotychczasowych rozwiązań teoretycznych.

Publikacja ta odpowiada na potrzeby współczesnej nauki (Novotny et al.). Autorzy, koncentrując uwagę na jednym złożonym zagadnieniu i prezentując je z różnych perspektyw badawczych, przekraczają granice interdyscyplinarności i wpisują się w szerszy dyskurs transdyscyplinarny. Zgodnie z jego wymogami monografia Edukacja - migracja. Edukacja międzykulturowa w kontekście kryzysu migracyjnego z perspektywy krajów V4 to swoista rama/platforma dyskursywna, która prezentuje wyniki badań nad migracją w taki sposób, by one wzajemnie dopełniały się, dając odpowiedź na najważniejsze, powszechnie formułowane pytania o inność kulturową w Europie. Wykorzystano różne perspektywy naukowe, jednak w odróżnieniu od badań interdyscyplinarnych, które polegają na oglądzie przedmiotu z różnych punktów widzenia i za pomocą metod przynależnych do wielu rozmaitych dyscyplin, redaktorki nie poszukiwały sumy wiedzy na dany temat, ale wykorzystały wyniki badań z różnych dyscyplin w celu znalezienia wspólnej odpowiedzi na pytanie: jak przygotować współczesne społeczeństwo do zmieniającej się bardzo dynamicznie struktury etnicznej nowej Europy? Jest to opracowanie, które wydobywa istotne problemy związane $\mathrm{z}$ tym procesem. Redaktorki, ujmując omawiane zagadnienia z perspektywy diachronicznej, sytuują je w szerszym kontekście, ponadto definiują niezbędne $\mathrm{w}$ ich opisie terminy i pojęcia, ułatwiając $\mathrm{w}$ ten sposób dyskurs społeczny, a także przenoszą go z przestrzeni intuicyjnej i emocjonalnej na obszar racjonalnych rozważań merytorycznych. Jest to proces badawczy zgodny ze współczesnymi koncepcjami teorii i filozofii nauki (Novotny, Scott, Gibbons) oraz z zasadami zarządzania wiedzą i kulturą.

Wstępna teza, że rozwiązaniem współczesnych problemów w ramach kategorii swój/obcy jest właściwie zaplanowana edukacja w zakresie komunikacji międzykulturowej, wpłynęła na porządek prezentacji zagadnień. Mając na uwadze to oraz główny problem ramy badawczej, należy uznać, że podział kompozycyjny monografii na cztery części:

1. prezentującą kontekst diachroniczny zagadnienia,

2. przedstawiającą najważniejsze aspekty praktyczne w zakresie glottodydaktyki i translatoryki,

3. opisującą postawy ksenofobiczne i ich konsekwencje społeczne,

4. wyjaśniającą podstawowe zagadnienia prawne, dotyczące kontaktów międzykulturowych,

jest w pełni uzasadniony. Pozwala zaproponować rozwiązanie najistotniejszych problemów oraz znaleźć odpowiedzi na najczęściej formułowane pytania.

W pierwszej części monografii zaprezentowano analizowane zagadnienie w kontekście diachronicznym, co konstruuje szerszą perspektywę badawczą, jednocześnie obiektywizując poruszane w kolejnych rozdziałach problemy. Autorzy, 
poszukując genezy obecnego stanu relacji międzykulturowych i zwracając uwagę na specyfikę tego procesu, dotychczas popełniane błędy i ich konsekwencje, przywołują istotne aspekty etyczne, towarzyszące ruchom migracyjnym.

Hanna Mamzer już na wstępie definiuje podstawowy problem badawczy, stanowiący ramę dla dalej prezentowanych analiz:

Edukacja w kontekście zróżnicowania kulturowego staje przed znaczącymi wyzwaniami, wynikającymi ze specyfiki kontekstu - społeczeństwa znajdującego się w sytuacji kryzysowej. W sytuacjach kryzysowych, które psychologowie definiują jako takie, które wymuszają modyfikację przyjętych sposobów funkcjonowania, stare bowiem okazują się nieadekwatne i nieefektywne. W takich sytuacjach umiejętność dostosowywania zachowań jest kompetencją bezcenną. Znajduje ona wyraz nie tylko na poziomie jednostkowym (kiedy to jednostka musi dostosować się do nowych wymogów rzeczywistości), ale też na poziomie społecznym, a co ważniejsze - instytucjonalnym (Edukacja - migracja 13).

Wspólnym, bezpośrednim lub pośrednim, celem autorów artykułów prezentowanych $\mathrm{w}$ niniejszej monografii jest odnalezienie poprzez edukację sposobu współistnienia w zmieniającej się kulturowo Europie. Przywołana teza Francisa Fukuyamy, że nadchodzi kres liberalnej polityki wielokulturowej, czego dowodem jest, według niego, nieskuteczna polityka europejska, która doprowadza do integracji społeczeństw mniejszościowych lub ich izolacji, wydaje się słuszna (Fukuyama). Trzy polityki wobec inności: asymilacyjna, integracyjna i wielokulturowa nie sprawdzają się i wymagają ponownej analizy (Stefańska).

W tym kontekście istotne staje się znalezienie odpowiedzi na pytanie o wybór postawy wobec Innego. Wskazanie teorii Jürgena Boltena, dotyczącej kształtowania kompetencji kulturowych jako narzędzia formowania pozytywnych postaw $\mathrm{w}$ relacjach interkulturowych, jest słuszne, jednak z pewnym zastrzeżeniem: by móc podnosić kompetencje w tym zakresie, potrzeba dużej rzeszy edukatorów, a tych $\mathrm{w}$ tak dynamicznie zmieniającym się świecie trzeba kształcić; istotne są w tym przypadku także możliwości kształcenia ustawicznego, aktualizującego dotychczasową wiedzę. Nie we wszystkich krajach ten problem jest dostrzegany. Składowe kompetencji Boltena: dwustronna tolerancja, dystans ról, elastyczność, empatia, gotowość do akulturacji, gotowość do interkulturowego uczenia się, metakomunikacja, umiejętność odróżniania struktur powierzchniowych i głębokich, otwartość, policentryzm, samodyscyplina, świadomość różnorodności myślenia, świadomość synergii, uznawanie granic akceptacji, wiedza kulturowa, zdolność do akomodacji, zdolność do komunikowania się i znajomość języków obcych wyznaczają ramy procesu edukacji w zakresie komunikacji międzykulturowej oraz edukacji w społeczeństwie wielokulturowym (Bolten). Wśród wymienionych kompetencji zwracają uwagę kompetencje emocjonalne: empatia, tolerancja, ela- 
styczność, dystans, otwartość - gotowość do akulturacji. Są to kompetencje często postrzegane jako wrodzone, jednak warsztaty, bezpośrednia komunikacja prywatna, odpowiednio dobrane teksty kultury mogą je uaktywnić, rozwinąć oraz wzmocnić. Zgadzam się z teorią, że problematyczna jest empatia, która nakazuje spojrzeć na świat oczyma innej osoby; jest to w pełnym zakresie bardzo trudne, czasem niemożliwe (Davis). Perspektywę i punkt widzenia kształtują nie tylko wiedza, ale także doświadczenia osobiste, tych zmienić nie można, będą one kreowały indywidualny obraz otaczającego świata. Rozwiązaniem wystarczającym mogą okazać się świadomość różnorodności myślenia i świadomość synergii. Według Mamzer, konieczne jest w kontekście opisywanych przemian rozwijanie metakompetencji o charakterze społecznym.

W pierwszej części wiele uwagi poświęcono także historii ruchów migracyjnych, pokazując, że nie jest to wyłącznie problem XXI wieku. Odwołując się do stwierdzenia Kazimierza Ilskiego, że wszyscy skądś przyszliśmy, że nie ma odwiecznych autochtonów (Ilski), Małgorzata Praczyk pokazuje optymistyczną i pesymistyczną perspektywę wędrówek ludów. Koncentruje swoją uwagę nie tylko na ruchach ponadpaństwowych, przywołuje także migracje wewnętrzne jako przyczynę konfrontacji kulturowych. We wnioskach autorki można znaleźć potwierdzenie tezy, że wymiana kulturowa, choć niełatwa, wzbogacała państwa Europy, stworzyła kształt społeczny naszego kontynentu, szczególnie Unii Europejskiej.

W tym pozytywnym kontekście istotne jest pytanie, czy obecne rozwiązania prawne Unii są wystarczające, by podołać nowym wyzwaniom. Odpowiedzi na nie udziela Antal Örkény. Teza, że dotychczasowy proces integracji Unii Europejskiej nie przysparzał większych problemów, jednak wyzwania imigracyjne ostatnich lat, weryfikując znane i utrwalone procedury, obnażają ich słabości, znajduje potwierdzenie $w$ przeprowadzonych przez niego badaniach empirycznych. Badacz zwraca szczególną uwagę na kształtowanie się postawy wobec obcego. Filozoficzny sens pojęcia obcy, zdefiniowanego w połowie XX wieku przez Alfreda Schütza jako antonim pojęcia swój (Schütz), nadal jest aktualny, jednak zyskuje wymiar ksenofobiczny, obcy to już często nie 'Inny', lecz 'wróg'. Autor zwraca także uwagę na bardzo istotny aspekt aksjologiczny zderzenia kulturowego w ramach Unii Europejskiej.

Rosnące w siłę partie populistyczne, opierające swoje programy na wizji państw narodowych, narastające konflikty na tle religijnym oraz brexit Wielkiej Brytanii pozwalają zaakceptować wniosek autora, że największym problemem współczesnej Europy jest pogodzenie kultur.

Poznając historię migracji, należy zwrócić uwagę na zróżnicowanie ruchów migracyjnych. Kinga Białek, prezentując kategorie migracji, uwzględniające różnorodne czynniki, wskazuje narzędzia opisu tego zjawiska. Najczęściej poruszanym problemem w publicznym dyskursie na temat ruchów ludności jest różnica między uchodźcą a imigrantem. Często rozpatrywana jest ona w ramach kategorii akcepta- 
cji: uchodźca - tak, imigrant - nie. Konwencje międzynarodowe definiują oba pojęcia. Zgodnie z Konwencją Genewską

uchodźcą jest osoba, która na skutek uzasadnionej obawy przed prześladowaniem z powodu swojej rasy, religii, narodowości, przynależności do określonej grupy społecznej lub z powodu przekonań politycznych przebywa poza granicami państwa, którego jest obywatelem, i nie może lub nie chce $\mathrm{z}$ powodu tych obaw korzystać $\mathrm{z}$ ochrony tego państwa, albo, która nie ma żadnego obywatelstwa i znajdując się na skutek podobnych zdarzeń, poza państwem swojego dawnego stałego zamieszkania nie może lub nie chce z powodu tych obaw powrócić do tego państwa (Ustawa o cudzoziemcach).

Autorka zwraca uwagę na moc sprawczą języka i zaleca opracowanie i upowszechnienie sposobów mówienia o inności takich, które nie będą generowały negatywnych emocji, będą natomiast pomagały nowym członkom Unii w adaptacji w świecie wielokulturowym.

Autorki tekstów zamieszczonych w drugiej części monografii koncentrują swoją uwagę na różnorodnych interkulturowych działaniach społecznych o charakterze poznawczym, np. kontekstach kulturowych translatoryki i glottodydaktyki. Helena Tužinská mierzy się z problemem przekładalności kulturowej tekstów, uwzględnia w swoich rozważaniach dokonania antropologów i psychologów. Bardzo cenne są jej spostrzeżenia pragmatyczne, wynikające z obserwacji poczynionych $\mathrm{w}$ obozie uchodźców.

Barierą, utrudniającą komunikację na granicy kultur, jest postawa etnocentryczna, której źródłem jest dziedzictwo narodowe. Beata Gromadzka zwraca uwagę, że przekonanie o wyższości kulturowej i własnej wyjątkowości ogranicza twórcze korzystanie z dorobku innych kultur, może też być przeszkodą w nabywaniu kompetencji międzykulturowych; zauważa, że ponowoczesna etniczność to kolaż kulturowy. Słusznie podkreśla, że komunikacja międzykulturowa nie jest izolowanym zagadnieniem edukacyjnym, powinna być elementem składowym całego procesu dydaktycznego, również edukacji polonistycznej.

Przywykliśmy opisywać świat, korzystając z trzech modeli relacji: monokulturowego, wielokulturowego i międzykulturowego (Boski). Izabela Skórzyńska zauważa, że modele te nie oddają w pełni złożoności kontaktów na granicy kultur i nie spełniają wszystkich oczekiwań. Przypomina o istniejącym od lat rozwiązaniu unijnym - „międzykulturowym uczeniu się", opartym na kilku podstawowych założeniach: równowartości kultur, możliwości oceniania kultur, szacunku do każdej kultury, złożoności kultur, równości ludzi wobec prawa, znaczeniu wartości, dopuszczalności odmienności ideologicznej. Autorka prezentuje kilka ćwiczeń, które pomogą przypomnieć i utrwalić te zasady.

$\mathrm{W}$ tekstach z omawianej monografii często wspominane są rola i ranga języka w budowaniu porozumienia na granicy kultur, dlatego tak istotna jest nauka przedstawicieli mniejszości języka dominującego na danym obszarze kulturowym. Jedno 
z rozwiązań metodycznych w zakresie glottodydaktyki zaprezentowała Małgorzata Zduniak-Wiktorowicz. Przedstawiona przez nią metoda projektowa nauczania słownictwa, sytuująca je w szerszym kontekście systemu języka, jest uzasadniona. Jednak obserwacja przeobrażeń w systemach leksykalnych współczesnych języków narodowych, odchodzenie od wyrazu słownikowego w kierunku pojęcia wydają się szczególnie ważne w kontekście komunikacji na granicy kultur. Warto opracować i wdrożyć projekt, który podniesie kompetencje ucznia-Innego w zakresie konotacji kulturowo-kontekstowych codziennych pojęć oraz ich waloryzacji. Zagadnieniem językowym, na które również warto zwrócić uwagę, jest nauczanie etykiety i innych werbalnych zachowań konwencjonalnych, brak tych kompetencji utrudnia bowiem kontakty w społeczeństwie zróżnicowanym kulturowo (Marcjanik).

Kolejna część opracowania opisuje postawy społeczne w relacjach z Innym. Islamofobia, antysemityzm i romofobia to trzy najczęściej rejestrowane, choć nie jedyne, postawy ksenofobiczne. Autorki, Monika Bobako, Małgorzata Wosińska i Emilia Kledzik, odwołując się do wyników własnych badań, w opisie relacji interpersonalnych w odmiennych kontekstach komunikacyjnych skoncentrowały swoją uwagę na podobnych, choć różnie przedstawianych, zagadnieniach: stereotypizacji, źródłach fobii, ich przejawach oraz wynikających z nich zagrożeniach. Prezentują własne spostrzeżenia w kontekście innych fobii etniczno-religijnych, wskazują ich podobieństwa i różnice. Istotnym walorem poznawczym tych tekstów są wskazane przez autorki rozwiązania, które pomogą zneutralizować negatywne postawy społeczne wobec Innego. Dotyczą one dwóch obszarów: edukacji społeczeństwa dominującego i ochrony prawnej każdego człowieka.

Bobako, omawiając genezę i przejawy islamofobii, definiuje pojęcie rasizmu, wprowadza także i objaśnia pojęcie orientalizmu. Przypomina o braku logiki w równorzędnym postrzeganiu ofiar i oprawców.

Wosińska wskazuje czynniki decydujące o przekształceniu się jednostkowych postaw negatywnych wobec Żydów w masowy antysemityzm. Interesujące są jej uwagi, dotyczące roli współczesnej postpamięci w umacnianiu antysemityzmu. Potwierdza to spostrzeżenie fakt, że wielu Polaków nigdy nie widziało Żydów i nie miało z nimi kontaktu, jednak formułują negatywne, generalizujące sądy o nich na podstawie odziedziczonego przekazu kulturowego.

Kledzik, przywołując wyniki swoich wieloletnich badań na temat relacji polsko-romskich, zauważa, że Romowie są postrzegani jako nieeuropejscy, orientalni, gorsi. Zwraca uwagę na istotny dla tej grupy mniejszościowej problem, mianowicie przypomina, że poza edukacją społeczeństwa dominującego na temat kultury romskiej ważna jest także edukacja Romów, która podniesie ich kompetencje komunikacyjne w obcym dla nich obszarze kulturowym. Uważa, że jest to droga do neutralizacji barier komunikacyjnych. Jednak najistotniejsze w jej rozważaniach jest zwrócenie uwagi czytelnika na wielokulturowość wspólnoty romskiej i wynikające stąd trudności w definiowaniu ich własnej tożsamości. 
Przedstawiciele społeczeństw dominujących, opisując Innych, często generalizują i uogólniają, nie dostrzegają wewnętrznego zróżnicowania tych grup, co jest istotnym problemem komunikacyjnym. Każdy Syryjczyk dla przeciętnego Polaka to Arab, czyli islamista, a w konsekwencji terrorysta. Takie myślenie nie ułatwia kontaktów interkulturowych, dlatego słuszna jest teza autorek, że najskuteczniejszą drogą do porozumienia jest właściwa edukacja.

Na szczególną uwagę zasługuje ostatnia część monografii, omawiająca zagadnienie agresji językowej z perspektywy prawnej. W dyskursie publicznym często pojawiają się stwierdzenia, że trudno ustalić, co już jest mową nienawiści, a co jeszcze nią nie jest; padają pytania o granice, których nie należy przekraczać. Zniesienie cenzury w państwach postkomunistycznych sprawiło, że wolność słowa przekształciła się $\mathrm{w}$ anarchię werbalną. Użytkownicy języków uznali, że można mówić wszystko o wszystkim, że nikt nie ma prawa nikomu ograniczać swobody wypowiadania się. Także $\mathrm{w}$ innych obszarach kulturowych powoli zaciera się różnica między wyrażaniem opinii a atakiem werbalnym, równolegle narasta powszechna potrzeba zdefiniowania mowy nienawiści.

Aleksandra Gliszczyńska-Grabias i Joanna Grabarczyk podjęły ten trud, wskazały identyfikatory prawne mowy nienawiści, opisały jej przejawy i skutki. Grabarczyk wskazała rozwiązania obowiązujące $\mathrm{w}$ innych krajach, eliminujące mowę nienawiści z przestrzeni publicznej, szczególnie elektronicznej. Gliszczyńska-Grabias zwróciła natomiast uwagę na brak adekwatnych, komplementarnych rozwiązań w polskim systemie prawnym, które umożliwiałyby konsekwentne i szybkie karanie za wszelkie przejawy dyskryminacji i nienawiści. Obie autorki wyposażyły czytelnika w wiedzę, która pozwala wyznaczać granice wolności słowa. Z tymi tekstami powinni zapoznać się nauczyciele i wychowawcy, którzy nie zawsze potrafią wyjaśnić swoim podopiecznym, dlaczego te lub inne wypowiedzi objęte są zakazem prawnym. Mogą one być ważne także dla moderatorów portali, blogerów i członków portali społecznościowych.

Ramę dyskursu transdyscyplinarnego na temat komunikacji międzykulturowej w kontekście kryzysu migracyjnego w Europie wyznacza wstęp obu redaktorek: Kledzik i Praczyk. Zwracają one uwagę, że narastająca fala agresji i nienawiści wobec Innego w przestrzeni publicznej wymaga natychmiastowej reakcji. Podkreślają, że istotną rolę $\mathrm{w}$ procesie naprawy relacji interkulturowych $\mathrm{w}$ Polsce może odegrać nowoczesna, przemyślana edukacja w tym zakresie oraz jej właściwe odzwierciedlenie w całym procesie dydaktycznym, co znajduje potwierdzenie między innymi w analizach Gromadzkiej.

Monografia Edukacja - migracja. Edukacja międzykulturowa w kontekście kryzysu migracyjnego z perspektywy krajów V4 to spójny przekaz naukowy, którego istotnym walorem jest umiejętne pogodzenie teorii z praktyką. Jest to lektura dla każdego, bez względu na profil jego wykształcenia, szczególnie polecam ją pedagogom, wychowawcom i nauczycielom. 
Autorzy tekstów, odpowiadając na zapotrzebowanie społeczne, podjęli trud rozwiązania wielu problemów z zakresu komunikacji kulturowej, zdecydowali się skategoryzować zjawiska, dotychczas opisywane doraźnie w ramach aktualnie prowadzonych badań, zdefiniowali wiele pojęć i terminów, interpretowanych dotąd intuicyjnie lub wyłącznie z perspektywy danej dyscypliny. Wyposażyli czytelnika w narzędzia, ułatwiające prowadzenie warsztatów oraz wykładów. Monografia ta, wspomagając obecną edukację społeczną, przyczyni się pośrednio do skutecznego rozwiązywania kolejnych problemów, które zrodzi wielka migracja międzykontynentalna w następnych latach.

\section{BIBLIOGRAFIA}

Bolten, Jürgen. Interkulturowa kompetencja. Przeł. Bolesław Andrzejewski. Poznań: Wydawnictwo Naukowe UAM, 2006.

Boski, Paweł. Kulturowe ramy zachowań społecznych: podręcznik psychologii międzykulturowej. Warszawa: Wydawnictwo Naukowe PWN, 2009.

Davis, Mark. Empatia. O umiejętności wspótodczuwania. Przeł. Jolanta Kubiak. Gdańsk: Gdańskie Wydawnictwo Psychologiczne, 1999.

Edukacja - migracja. Edukacja międzykulturowa w kontekście kryzysu migracyjnego z perspektywy krajów V4. Red. E. Kledzik, M. Praczyk. Poznań: Media Rodzina, 2016.

Fukuyama, Francis. „Klęska wielokulturowości”. Przeł. Sergiusz Kowalski. Gazeta Wyborcza 29 (2007).

Hatalska, Natalia. Wędrowcy. Raport o wspótczesnych nomadach. Web. 03.04.2017.

<https://prowlyuploads.s3.amazonaws.com/uploads/landing_page_image/image/47730/Raport_W_drowcy.pdf>

Ilski, Kazimierz. „Consortia Vivendi”. Obrazy migracji. Red. K. Ilski, Poznań: Instytut Historii UAM, 2010. S. 97-108.

Marcjanik, Małgorzata. Grzeczność w komunikacji językowej. Warszawa: Wydawnictwo Naukowe PWN, 2007.

Novotny Helga et al. The New Production of Knowledge: The Dynamics of Science and Research in Contemporary Societies. Londyn - Thousand Oaks - New Delhi: Sage Publishing, 1994.

Novotny Helga, Scott Peter, Gibbons Michael. Rethinking Science - Knowledge and the Public in an Age of Uncertainty. Cambridge: Polity Press, 2003.

Schütz, Alfred. „Obcy: esej z zakresu psychologii społecznej”. O wielości światów. Szkice z socjologii fenomelogicznej. Red. A. Schütz. Kraków: Zakład Wydawniczy Nomos, 2012. S. 213-222.

Stefańska, Renata. „Między multikulturalizmem a asymilacją? Polityki integracyjne w Europie”. Problemy integracji imigrantów: koncepcje, badania, polityki. Red. A. Grzymała-Kazłowska, S. Łodziński. Warszawa: Wydawnictwa Uniwersytetu Warszawskiego, 2008. S.123-155.

Ustawa o cudzoziemcach, 12.12.2013, Dz.U.2013 poz.1650. 